MACIEJ GÓRNY

The Tadeusz Manteuffel Institute of History

Polish Academy of Sciences, Warsaw

\title{
'FIVE GREAT ARMIES AGAINST OUR ENEMIES'. A COMPARATIVE STUDY IN THE HISTORY OF RACISM
}

Two figures are cast as the heroes of the paper. The first, Jean-Louis Armand de Quatrefages de Bréau ranks among a great number of nineteenth-century anthropologists who, although they broke no new ground in their discipline, played an important role in institutionalizing it. The second, Franciszek Henryk Duchiński, was an ethnographer-amateur, brought up in the Polish-Ukrainian milieu. Beginning in the 1840s, he was active in the circle of Polish exiles. Serious doubts have been raised as to whether he belongs in the history of science. ${ }^{1}$ Both Quatrefages and Duchiński were the authors of racial theories that have long been regarded as eccentric. However, if the French author is usually accorded a prominent place in works on the ideology of racism and the history of science, then the Polish-Ukrainian scholar has never been given that kind of recognition.

J.-L.A. de Quatrefages de Bréau (1810-92) was a French anthropologist and zoologist. Co-founder, along with Isidore Geoffroy Saint-Hilaire and Paul Broca, of the Paris Anthropological Society, he was unstinting in his efforts to popularize science, sitting on a number of French and foreign scholarly associations. ${ }^{2}$ He studied in Strasbourg where he was later employed as a lecturer teaching chemistry, physics and - after

${ }^{1}$ Stanisław Grabski noticed that 'Duchiński is not a scholar in the strict sense of the term [...]. He harnessed his pen in the service of his country and his works were designed to protect its interests.' Idem, Życie i działalność literacka Franciszka Duchińskiego Kijowianina, in Franciszek Henryk Duchiński, Pisma, 3 vols, Rapperswil 19011903, vol. 1, p. V.

${ }^{2}$ On the beginnings of the French Anthropological Society see Kamil Popowicz, Lamarkizm społeczny a rasizm i eugenika we Francji, Warsaw, 2009, pp. 149-57. For more on Quatrefages's life see D. Ferembach, ‘Jean Louis Armand de Quatrefages de Bréau (1810-1892)', International Journal of Anthropology, 4, 1989, pp. 305-07. 
completing his education - medicine. From 1833, he worked as a doctor in Toulouse, where he founded the Journal de Médicine et de Chirurgie de Toulouse. After moving to Paris in 1840, he focused exclusively on the study of the problems of anthropology. An opponent of Darwin's theory, he was - according to his Polish translator - one of the very few whose criticism of Darwin's views 'sprang from a pure source of science'. ${ }^{3}$ A Member of the Academy of Sciences and - from 1879 - the Royal Society of London, he was awarded membership of the Légion d'Honneur. Towards the end of his life, he presided over the Geographical Society (Société de Géographie) of which he had been a member since 1856.

F.H. Duchiński's life did not follow the pattern typical of a scholar. ${ }^{4}$ Duchiński himself seems to have been very concerned about his image, inserting in his works a great number of autobiographical notes which convey the impression of an unorthodox career. He was born in Ukraine in a petty noble family. His father died when he was young, and his mother Zofia (née Bojarska) worked as a governess in the house of Count Tyszkiewicz to maintain herself and her two sons. After she died in 1829, Franciszek attended the Basilian school in Humań and later worked at a school for girls in Niemirów. In 1834 he moved to Kiev where - by his own account - he entered the Historico-Philological Faculty of the University. For a time he earned a living as a private tutor and he states that he was active in the students' organization called the Association of the Polish People. Duchiński avoided persecution after Szymon Konarski's arrest, and he remained in Kiev until the mid-1840s. In 1846 he traveled to Turkey via Odessa and then he moved to Paris. In France he began to work closely with the 'May the Third' organization. Joining the Polish Legion organized in Italy in 1848 , he launched himself into propaganda activity and later served as a Polish representative, affiliated to the Istanbul legation of the Hungarian insurrectionary government. Following the defeat of the Hungarian uprising in 1849, he served as Prince Adam Czartoryski's agent in the Balkan region. It was at that time that he be-

\footnotetext{
${ }^{3}$ Julian Ochorowicz, 'Kilka słów tłomacza', in Adolf [sic!] Quatrefages, Karol Darwin i jego poprzednicy. Studium nad teoria przeobrażeń, Warsaw, 1873, p. III.

${ }^{4}$ Some basic biographical information is included in Grabski, Życie, p. I-XXXIV; August F. Grabski, 'Na manowcach myśli historycznej. Historiozofia Franciszka H. Duchińskiego', in idem, Perspektywy przeszłości. Studia i szkice historiograficzne, Lublin, 1983, pp. 226-39; Maria Czapska, 'Franciszek Henryk Duchiński', in: PSB, vol. 5, Kraków, 1939-45, pp. 441-43. Affirmative sketches on Duchiński including biographical data can be found in Agaton Giller, 0 życiu i pracach F.H. Duchińskiego Kijowianina w jubileuszowa rocznicę pięćdziesięcioletnich jego zasług naukowych, Lwów, 1885; Seweryna Duchińska, Młode lata Franciszka Duchińskiego uzupetnione rzutem oka na jego działalność naukową, Lwów, 1897.
} 
gan to publish his first studies in ethnography and anthropology on Russia and Ukraine. Absolved from his duties on the eve of the Crimean War, Duchiński stayed in the Balkans, publishing his articles in the Journal de Constantinople. In 1855 he entered English service. Officially appointed to a position of 'superintendent', entrusted with the task of supervising railway workers, he actually delivered propaganda speeches intended for British, French, and Turkish soldiers. On his return to Paris in 1856 he found employment in the Polish Higher School. In Paris he also delivered public lectures, and continued to publish. He was offered a place in the French Ethnographic Society, rising in 1871 to the position of vice-chairman. He was one of the editors of Actes de la Société d'Ethnographie and in 1865 joined the French Geographical Society. At that time he could pride himself on two important victories which he won in the pursuit of his 'public mission'. First, his efforts led to a change in the name of the Chair of Slavic Literature at the Collège de France. From then on, it was to be called 'the Chair of Slavic Literatures'. ${ }^{5}$ Second, relying on the support of a French journalist and deputy, Casimir Delamarre, and a celebrated historian, Henri Martin, Duchiński managed to modify the content of some of the courses in the history of Eastern and Central Europe taught at French schools. At the beginning of the 1870s, after a short stay in Galicia, Germany, and Austria, he took up the post of curator at the Polish National Museum in Rappersvil. All his attempts to obtain a chair at the Jagiellonian University were to no avail. Nevertheless, he continued to publish articles in Polish and Ukrainian journals in an effort to promote his anthropological views. In Kraków, Duchiński even founded Przeglą Etnograficzny [the Ethnographical Review] and in 1878 he was involved in the organization of the Polish stand at the Universal Paris Exhibition. In 1885 in Lwów (Lemberg, L'viv) he celebrated the fiftieth anniversary of his scholarly work. He died one year after Quatrefages, and his obituary was published in the Ethnographic Society's newsletter. ${ }^{6}$

With time, the treatment accorded to both anthropologists drifted increasingly apart. Quatrefages's scholarly achievements, although long passé, established his place in the history of zoology and anthropology. It was not so with Duchiński. His work attracted the attention of schol-

${ }^{5}$ Leszek Kuk, 'Zmiana nazwy katedry słowiańskiej Collège de France w roku 1868. Z dziejów stosunku Francji wobec tzw. kwestii słowiańskiej w XIX wieku’, in Publicyści późniejszego romantyzmu wobec rządów zaborczych i spraw narodowościowych na ziemiach dawnej Rzeczypospolitej, ed. Sławomir Kalembka, Toruń, 1998.

${ }^{6}$ Georges Barclay, 'Rapport annuel fait à la Société d'Ethnographie sur ses travaux et sur les progrès des sciences ethnographiques pendant l'année 1893', Bulletin de la Société d'Ethnographie, 35, 1893, 76, pp.123-24. 
ars interested in the history of historiography, but has remained largely ignored by historians studying the development of other scholarly disciplines.

In the 1980s Andrzej Feliks Grabski published a thorough study of Duchiński's historical thought. ${ }^{7}$ Some references to his political activities can be found in works by Marceli Handelsman and Jerzy Skowronek, ${ }^{8}$ while his ideas have been discussed and commented on by Andrzej Wierzbicki and several other scholars. ${ }^{9}$ Duchiński's writings on Ukrainian issues have been dealt with by Ivan L. Rudnytsky who attempted to trace the way in which his views were received in the context of the Ukrainian nation-making process. ${ }^{10}$

Analysis of Duchiński's works leaves one convinced that the conclusions of scholars who have studied his thought are fully justified. The academic literature on which he drew, the scholarly apparatus with which he presented his works, and the learned societies to which he belonged were all used to advance a theory which carried overtly political connotations. The belief that Russians were of non-Slavic origin was his idée fixe: 'It is a grave error - common though that is - to try to understand the ties that link the Slavic nations by the study of their languages, hoping that their true nature can be probed into only through the analysis of some words carried out in a way developed by Dubrowski'. ${ }^{11}$ Duchiński was of the opinon that it is only in view of the impossibility of carrying out ethnographic studies that language analysis can be resorted to [...] which however should be carried out with an awareness that its results will always remain questionable and open to debate, since languages used by different nations evolve and lend themselves to change'. ${ }^{12}$ Anthropol-

${ }^{7}$ Grabski, 'Na manowcach myśli historycznej’.

${ }^{8}$ Marceli Handelsman, Adam Czartoryski, 3 vols, Warsaw, 1948-50, vol. 2, 1949, pp. 180, 276, vol. 3, pp. 483-84; idem, Ukraińska polityka księcia Adama Czartoryskiego przed wojna krymska, Warsaw, 1937, pp. 109-24, 145-50; Jerzy Skowronek, Polityka batkańska Hotelu Lambert (1833-1856), Warsaw, 1976, p. 151.

${ }^{9}$ Andrzej Wierzbicki, Spory o polska duszę. Z zagadnień charakterologii narodowej w historiografii polskiej XIX i XX wieku, Warsaw, 2010, pp. 198-200; idem, Groźni i wielcy. Polska myśl historyczna XIX i XX wieku wobec rosyjskiej despotii, Warsaw, 2001.

${ }^{10}$ Ivan L. Rudnytsky, 'Franciszek Duchiński and his Impact on Ukrainian Political Thought', in idem, Essays in Modern Ukrainian History, ed. Peter L. Rudnytsky, Edmonton, 1987, pp. 187-202.

${ }^{11}$ Franciszek Henryk Duchiński, 'O stosunkach Rusi z Polską i z Moskwą zwaną dzisiaj Rosją. O potrzebie dopełnień i zmian w naukowym wykładzie dziejów polskich. Przy otwarciu roku szkolnego Szkoły Wyższej Polskiej w Paryżu, przy bulwarze Mont Parnasse w dniu 7 listopada 1857 r.', in idem, Pisma, vol. 1, p. 64. The author was referring to the work of the illustrious Czech linguist Josef Dobrovský (1753-1829).

${ }^{12}$ Franciszek H. Duchiński, 'Zasady dziejów Polski i innych krajów słowiańskich i Moskwy', part 2, in idem, Pisma, vol. 2, p. 113. 
ogy, or as Duchiński called it, ethnography, was a far more suitable method of investigation than any form of language study.

According to Duchiński, the white race is divided into Aryans and Turans. The former, comprising Slavs, Germans, and Latins, live in the region of Europe which stretches as far east as the Dnieper river. The latter, made up of Turks, Finns, and Mongols inhabit territories that lie east and south of Ukraine. The latter are still nomadic or have preserved nomadic characteristics beneath a thin layer of civilization.

'The traits of the Aryan people' - says Duchiński -

are a fair reflection of the freedom for which they seem to have been specifically born: deeply attached to their land, they love agriculture for its own sake and not for the trading opportunities it provides. Their provincial life is thriving, individual self-reliance deeply inculcated, property rights respected, and the family name highly venerated. Feeling a deep love for their country, they are ready to make great sacrifices in its defence as well as in the furtherance of its welfare. Very emotional, but capable of controlling their passions with reason, they are blessed with a power of perseverence and creativity which they have so far been able to turn to their advantage in a variety of ways [...]. Women are held in great regard in their societies. ${ }^{13}$

Turans, by contrast,

passive by nature, have displayed no originality of mind, having to content themselves with the ability to imitate others. Their blind fanaticism comes in the guise of religious devotion [...]. In their society, organized along military lines, the woman ranks low, which, for example, can clearly be seen among Turks [...]. Ages have elapsed. With the progress of civilization, the last vestiges of nomadism have disappeared in Europe without a trace, but the descendants of the old nomads have preserved their fathers' propensities. ${ }^{14}$

Duchiński was particularly concerned with one branch of Turans: the Muscovites whom he refused to count as a Slavic people. Cultural imports into Russia (that is, via Ukraine), made possible through the influence exercised by Kievan Rus', could not result in transforming the essential characteristics which typify the Finno-Mongol people. This belief led him to formulate some original views concerning Russia's history and geography. He argued that the Ural Mountains could not be regarded as marking

${ }^{13}$ Idem, 'Pierwotne dzieje Polski', in idem, Pisma, vol. 3, pp. 15-16.

${ }^{14}$ Ibid., pp. 17-18. 
a boundary between Europe and Asia - a conclusion which could be justified on the grounds that the areas on both sides of the Urals, ridges were populated by the same people. When judged from Moscow's point of view, claimed Duchiński, the Tatar invasion should be treated as a blessing:

The invasions of Mongols and Tatars did not result in the separation of Moscow from Ruthenia as there had never been a bond of moral unity between the two. Quite the contrary, the invasions were beneficial in fostering the 'laws of race' to be followed by the Muscovites - by merging such tribes as the Suzdal, Wess, Myera, Muromians, and Chuvash with the Muscovites whose settlements ranged over the region of Kazan and behind the Oka river and who remained under the rule of national khans. [...] Thus the conquest of Genghis Khan should not be viewed as harming but rather as benefiting the Suzdal Muscovites, since it served to engender laws of tribal purity which are even more craved for by pastoral and mercantile societies than by Indo-European ones. ${ }^{15}$

Racial differences were in Duchiński's opinion permanent. He stated that he would be happy to see Russia free and Catholic, but, he added, 'even free and Catholic Russians will remain different from Indo-Europeans in the mission with the execution of which they had been entrusted here on earth. ${ }^{16}$ For Duchinski the Europeanization of Russia was nothing but a chimera.

The Muscovites distinguish themselves from Europeans in general, and from the 'real' Ruthenians in particular, by both their appearance and mentality. This point, which Duchiński believed could be seen with the naked eye, was to serve as the evidence supporting his thesis about racial differences. 'Indo-European people' - he wrote in one of his works -

are physically more refined while the Turanian people constitute an unformed mass, just raw and unprocessed meat. The head of these people has barely come out of the nape of their necks, it simply has not yet fully set itself apart from their back and their legs have barely sprouted out of their loin. [...] What strikes you the moment you see a Muscovite is neither a face nor a head, but a neck. The neck is simply the essence of the Muscovite. With the neck too big in proportion to the head, and generally to the rest of the body, their noses are as upturned as to leave the hair inside clearly visible. ${ }^{17}$

${ }^{15}$ Idem, 'Zasady dziejów Polski i innych krajów słowiańskich i Moskwy', part 3, in idem, Pisma, vol. 2, p. 243.

${ }^{16}$ Idem, Odezwa do ziomków, Paris, 1861, p. 3.

${ }^{17}$ Idem, 'Galeria obrazów polskich. Oddział pierwszy. Różnice ludów indoeuropejskich a turańskich pod względem fizjonomii i odzieży’, in idem, Pisma, vol. 3, pp. 212-14. 
Therefore, it should not be doubted that 'these two human beings, the Muscovite and the Ruthenian, just need to cast a glance at each other to know that they have nothing in common'. ${ }^{18}$

According to Duchiński, it is also as a society that the Muscovites were repulsive. The word 'morality' was foreign to them. 'Generally in Moscow, and especially in relation to women, there is no other morality than that engendered exclusively by, and existing only within the confines of, the code of law, with police officers always serving as its custodians'. ${ }^{19} \mathrm{Du}-$ chiński compared Russian women to 'emancipated Muslim women', denying their intellectual and legal independence, denouncing their indifference towards land ownership, and complaining about the 'absence of any uplifting fables from the history of their own sex'. ${ }^{20}$ Moscow differed from Europe in almost everything: population density, landscape and climate.

The line of reasoning presented above rested on a particular set of data. Ethnographic maps, prepared by Alfred Ciszkiewicz, secretary to L'École Spéciale d'Architecture in Paris, were included in some of Duchiński's books. In creating the maps, Ciszkiewicz followed the instructions given by Duchiński himself. East of the Dnieper River, the maps show the mosaic of the Turanian people, while the category of Russians remained entirely absent from them. One such map was to be presented during the anthropological exhibition organized as part of the Paris Universal Exposition in 1878. Henryk Sienkiewicz who saw the exhibition made some approving, though hardly detailed, comments on it: 'Ciszkiewicz's ethnographic map offers a good description of the tribes that inhabit our lands and is likely to be of some use in resolving scholarly disputes'. ${ }^{21}$ Duchiński's argument was that used in craniology, which was then undergoing dynamic development, by claiming that skull measurements, too, lent credence to his theory. ${ }^{22} \mathrm{He}$ illustrated his disquisitions concerning social ills found in the Tsarist Russia with statistical tables. ${ }^{23}$

${ }^{18}$ Ibid., p. 216.

${ }^{19}$ Idem, Pomnik nowogrodzki. Periodyczne wyjaśnienia projektu rządu moskiewskiego, aby uroczyście obchodzić w następnym 1862 r.,jakoby tysiac-letnią rocznicę założenia dzisiejszego państwa moskiewskiego w Nowogrodzie, miewane publicznie (obecnie w Paryżu), Paris, 1861, p. 15.

${ }^{20}$ Idem, 'Pomnik nowogrodzki. Periodyczne wyjaśnienia projektu rządu moskiewskiego, aby uroczyście obchodzić w następnym 1862 r.jakoby tysiąc-letnią rocznicę założenia dzisiejszego państwa moskiewskiego w Nowogrodzie', in idem, Pisma, vol. 3, p. 170.

${ }^{21}$ Henryk Sienkiewicz, 'Z wystawy antropologicznej w Paryżu', Nowiny, 42, 11 August 1878 .

${ }^{22}$ See, for example, Franciszek H. Duchiński (de Kiew), Peuples aryâs et tourans, agricultureurs et nomades. Nécessité des réformes dans l'exposition de l'histoire des peuples Aryâs-européens \& Tourans, particulièrement des Slaves et des Moscovites, Paris, 1864, p. XXX.

${ }^{23}$ Cf. ibid., pp. 82-90. 
Thus, Duchiński placed great importance upon maintaining a wide scholarly network, a matter to which we shall return later.

On the eve of the January Uprising of 1863 he sought to obtain, however unsuccessfully, subsidies for the 'Revue, to be published in French with a view to disseminating my principles'. ${ }^{24}$ All his efforts were based upon the belief that 'the world is governed by either good or bad science'. ${ }^{25}$

Duchiński's theories have received strong criticism from modern historians. The interpretation put forward by Andrzej Feliks Grabski remains fully justified. Grabski demonstrated that it was the influence of Joseph Arthur de Gobineau that hung heavily upon the oeuvre of Duchiński whose works are permeated with aggressive nationalism and extreme conservatism. ${ }^{26}$ In this context, Andrzej Walicki mentioned Cyprian Kamil Norwid's remark that asked rhetorically: 'How can one remain a religious person after subordinating all dimensions of the history of human beings to strict laws of racial development and ethnographic conditions?'. ${ }^{27}$ Rudnytsky, however, is inclined to take a more positive view of the political influence that Duchiński's racial theories exerted upon the Ukrainian nation-making process. ${ }^{28}$ What links all the scholars mentioned above is the fact that their analyses have been confined only to the history of ideas Polish or Ukrainian. When approached from this angle, the question of the extent to which Duchiński may have influenced foreign authors is only of secondary importance and remains unexplored. It is, therefore, worth taking this neglected approach to Duchiński's work.

In a recently published paper on the French 'turanism', Marléne Laurelle has noted with some discomfort that the teacher from the Polish lyceum managed to influence some prominent figures of French public life: Henri Martin, Albert Reville, August Vicquesnel, Charles de Steinbach, Casimir Delamarre, Édouard Talbot, Emmanuel Henri Victurnien marquis de Noailles, Élias Regnault and others. ${ }^{29}$ As she says, in the 1860s the 'Turan' thesis became one of the main elements of French Russophobia..$^{30}$ The examination of the case of H. Martin, the most distinguished of the French advo-

${ }^{24}$ Idem, Odezwa do ziomków Kijowianina Duchińskiego, Paris, 1862.

${ }^{25}$ Ibid., p. 44.

${ }^{26}$ Grabski, 'Na manowcach myśli historycznej'.

${ }^{27}$ Cyprian Kamil Norwid, Pisma wszystkie, ed. Juliusz W. Gomulicki, 11 vols, Warsaw, 1971-76, vol. 10, 1971, p. 102, quotation from Andrzej Walicki, Między filozofia, religią i polityką. Studia o myśli polskiej epoki romantyzmu, Warsaw, 1983, p. 217.

${ }^{28}$ Rudnytsky, 'Franciszek Duchiński', pp. 187-202.

${ }^{29}$ Marléne Laurelle, 'La Question du "touranisme" des Russes. Contribution à une histoire des échanges intellectuels en Allemagne - France - Russie au XIe siècle', Cahiers du Monde Russe, 45, 2004, 1-2, p. 17.

${ }^{30}$ Ibid., p. 61. 
cates of Duchiński's theories, enables one to trace the influence the latter exercised upon the way in which Russians were perceived by some authors in France. Although favourably inclined towards the Poles, and involved in publishing pro-Polish articles during the 1863-64 Uprising, Martin at first remained sceptical about Duchiński's theories. ${ }^{31}$ However, having listened to a number of lectures delivered by the Pole, he changed his mind and even sent Duchiński a letter in which he informed him of his new attitude (and Duchiński of course did not neglect to publish some of its fragments). 'The Muscovites, Turans by race and spirit, are not part of a European community; they sow confusion and disorientation; they will never become a harmonious element'. ${ }^{32}$ Two years later, he published a book, La Russie et l'Europe, in which he repeated almost in extenso all Duchiński's theses. ${ }^{33}$ In the conclusion he wrote: 'the Muscovite is alien to the European family'. ${ }^{34}$ Other French advocates of Duchiński's theory also developed a habit of repeating his views - sometimes to the point of laying themselves open to charges of plagiarism, for they included no footnotes. Many times they repeated the view that Nestor was a Polish chronicler. Without crediting the source, they also drew on Duchiński's French translation - the first ever of some excerpts of Karamzin's works. ${ }^{35}$

It was no different with Duchiński's attempts to delimit the areas ostensibly inhabited by Indo-Europeans. The only work that stood out from the remainder of the French publications indebted to Duchinski's ideas was that presented by É. Regnault. He offered a systematic classification of Duchiński's views, dividing them according to different categories: geological, hydrographic, ethnographic, and those pertaining to the type of soil, customs and social norms. He also made some references to the criticism of Duchiński's theories - whose name was mentioned several times in his study $^{36}$ - raised by Russian scholars, or by those who represented Russian institutions. The 'politics of history' pursued by the Hôtel Lambert faction

${ }^{31}$ See Henri Martin, Pologne et histoire, Paris, 1863. This work collecting articles that had originally been published in various newsapers did not touch on racial questions at all.

32 'Les Moscovites, touraniens de race et de génie, ne sont pas de la société européenne; ils la troublent et la désorganisent; ils n'en seront jamais un élément harmonique', Duchiński (de Kiew), Peuples aryâs et tourans, p. VII.

${ }^{33}$ Henri Martin, La Russie et l'Europe, Paris, 1866, especially pp. II-III, 8-17 and 98-120.

34 'Le Moscovite, étranger à la famille européenne', ibid., p. 259.

${ }^{35}$ See, for example, the map included in the work by A. Charlier de Steinbach, La Moscovie et l'Europe. Étude historique, ethnographique et statistique, Paris, 1863.

${ }^{36}$ Élias Regnault, La question européenne improprement appelée polonaise. Réponse aux objections présentées par M. M. Pogodine, Schédo-Ferroti, Porochine, Schnitzler, Soloviev, etc., contre le polonisme des provinces lithuano-ruthènes et contre le non-slavisme des Moscovites, Paris, 1863, pp. 7-10 and 149-53. 
played a noteworthy, but secondary, role in the history of the French reception of Duchiński's work. The Kiev scholar often relied on the financial support of the Czartoryski family. Some of his French publications appeared thanks to subsidies he received from the Treasury Office. However, it needs to be said that some of his advocates, including Regnault, could count on the same kind of support. ${ }^{37}$

One can indicate several factors that stood behind the specificity characterizing Duchiński's presence in the works of French authors who drew on his theories. The first and perhaps the most important one concerned Duchiński's way of treating his theses (and actually one main thesis). He considered their dissemination to be his quasi-religious duty, regarding his scholarly efforts as serving a patriotic purpose of liberating Ruthenia which was to be forever united with Poland. In his proclamation to the insurrectionary government in 1863 he declared: 'We are going to deprive the Muscovites of part of their strength by employing their own methods of fighting, that is, by exercising the right of naming. We are going to make the Muscovites go by the name of the Muscovites, denying their right to use names which they have appropriated in an effort to legitimate the annexation of the greater part of Poland, Ruthenia'. ${ }^{38}$ Motivated by a sense of mission, he was not troubled by the question of whether his French followers were willing to acknowledge openly their intellectual debt. The Polish ethnographer clearly was prepared to content himself with some sort of a tacit partnership. His wife, Seweryna Duchińska, who left Poland after the fall of the January Uprising, reminisced about his passion for promoting works by other authors. Not only was he in the habit of encouraging their publications, but sometimes also had a hand in writing them.

Before the publication of Martin's work on Poland and Russia 'the Post Office sent in stacks of cards to the French historian's residence address on Rue Montparnasse'. ${ }^{39}$ Moreover, prior to the enactment of the changes in the French school curriculum, Duchiński worked closely with C. Delamarre. ${ }^{40}$ Providing the authors whom he had befriended with statistical data and scholarly works he had been collecting over a long time, he felt no need to prevent them from copying this material into their own works, which were soon to be published under their own names.

37 See Władysław Czartoryski, Pamiętnik 1860-1864. Protokoły posiedzeń biura Hotelu Lambert part. I and II. Entrevues politiques, Warsaw, 1980, pp. 211, 218 and 296.

${ }^{38}$ Franciszek Henryk Duchiński, Do Rządu Narodowego Powstańczego od będącego obecnie na służbie krajowej w Paryżu Kijowianina Duchińskiego przedstawienie, Paris, 1863, p. 6.

${ }^{39}$ Seweryna Duchińska, Wspomnienia z 29cio-letniego pożycia z mężem moim 18641893, Paris, 1894, p. 27.

${ }^{40}$ Ibid., pp. 69-70. 
The second factor which can explain the fact that Duchiński was not given sufficient acknowledgement in French works on Turanian people was his fear of eliciting a hostile reaction from the Russian authorities. His conjecture that he was being followed turned out to be true. ${ }^{41}$ His wife argued that in 1865 , following the intervention of the Russian embassy, her husband had to give up delivering his public speeches, thus having been left with no other option but to confine himself to writing. ${ }^{42}$ The adherence to his principles was also to hinder the careers of his French friends. Duchińska recollected that 'by working so closely with Vicquesnel, my husband had to put up with a great deal of disagreeable remarks from Vicquesnel's wife. That proud and wayward woman grumbled bitterly that her husband, despite huge accomplishments to his credit, had not yet been awarded the Cross of the Légion d' Honneur. This failure was the result of the excessively cautious conduct of the Bonapartists and other doctrinaires who were afraid of offending the Muscovites resentful at the exclusion from the Slavic World'. ${ }^{43}$ Duchiński's role in preparing the anthropological Exhibition in 1878 was also to be more crucial and more important than was officially acknowledged. In this case, too, it was the fear of the 'north wind' blowing from St Petersburg that was to blame for hiding the Polish scholar's contribution to the organization of this event. $^{44}$

Duchiński's theories also reverberated throughout German-speaking countries. Delamarre's pamphlet was published in German (it was translated into German by one of Duchiński's acquaintances - Charlier de Steinbach) in parallel with Emperor Napoleon III's order enacting the change in the name of the Chair of the Slavic Literatures at the Collège de France. ${ }^{45}$ In his pamphlet Delamarre expressed astonishment that such sterling scholars as Germans still permitted themselves to be deceived by Russian propaganda. The French author tried to blame it on, at least in part, some extra-scholarly factors: 'It is a Slavic scholar, Mr Duchiński of Kiev, to whom we owe these new ideas. And perhaps it is his origin that is in part responsible for German scholars' distrust with which they have treated his theories' ${ }^{46}$ Contrary to this opinion, Duchiński's ideas met with the approval of

${ }^{41}$ See Grabski, ‘Na manowcach myśli historycznej’, p. 235.

${ }^{42}$ Duchińska, Wspomnienia, p. 38.

${ }^{43}$ Ibid., pp. 30-31.

${ }^{44}$ Ibid., pp. 171-72.

${ }^{45}$ Casimir Delamarre, Ein Volk von fünfzehn Millionen Seelen welches von der Geschichte vergessen worden ist. Eine Petition an den französischen Senat, Paris, 1869.

46 'Diese Reformen verdanken wir allerdings einem slawischen Gelehrten, dem Herrn Duchinski aus Kiew, und das ist vielleicht ein Grund für manchen deutschen Geschichtsforscher, eine gewisse Abneigung gegen dieselben zu hegen', ibid., p. 5. 
some German authors who, unlike their French colleagues, fully recognized his role in proving Russia's true ethnic nature. The theory also attracted the attention of Karl Marx. ${ }^{47}$ But it was an archeologist and historian from the Polytechnic in Zurich, Gottfried Kinkel, who tried to probe deeper into the theory by writing two extensive papers on it. ${ }^{48} \mathrm{He}$ also wrote enthusiastic reviews of Duchiński's 'Swiss' lectures. The reviews appeared in Neue Zürcher Zeitung and in Vienna's Neue Freie Presse.$^{49}$ It was also in Vienna that one of Emil Hervet's pamphlets, translated into German, was published. ${ }^{50}$ Duchiński's 'Turan' theory was well-received by Austrian ethnographers, and - importantly for the foreign reception of Duchiński's work - the acceptance it gained in the circle of Austrian scholars had nothing to do with the latter's anti-Russian prejudices. They regarded it as expressing objective facts which were helpful, although not crucial, in explaining the 'ethnogenesis' of the Ruthenian inhabitants of the Austrian Empire. ${ }^{51}$

In Poland Duchiński was considered a controversial thinker. Both at home and in exile he had as many avid adherents, who were deeply convinced of the validity of his views, as opponents for whom his theories were entirely without foundation. Przeglad Rzeczy Polskich (The Review of the Polish Affairs) discussed Duchiński's theses in a polemical exchange with Aleksandr Herzen and Nikolai Ogarev. ${ }^{52}$ Henryk Kamieński passed his theory under a critical review. ${ }^{53}$ In Galicia Stefan Buszczyński served as a reliable distributor of Duchiński's ideas. There was clearly an irony

${ }^{47}$ In a letter to Friedrich Engels written in 1865 Marx subscribed to Duchiński's theory. For Marx the theory's practical consequences were more important than its verification. 'Ich wünsche' - he wrote - 'daß Duchiński recht hat und at all events diese Ansicht herrschend unter den Slawen würde'. Karl Marx to Friedrich Engels, London, 24 June 1865, in Karl Marx and Friedrich Engels, Werke, 43 vols, Berlin, 1956-90, vol.31,1973, p.127. A few years later the philosopher arrived at the conclusion that Duchiński went too far in pursuing his theory. Marx himself tended to subscribe to the view that Mongol origin could be proved only in relation to the Russian élites: Karl Marx to Ludwig Kugelmann, London, 17 February 1870, in Marks and Engels, Werke, vol. 32, 1974, pp. 649-51.

${ }^{48}$ Gottfried Kinkel, Polens Auferstehung - die Stärke Deutschlands, Vienna, 1868; idem, La Renaissance de la Pologne envisagée comme la force de l'Allemagne, Zürich, 1868.

${ }^{49}$ Quotations in Delamarre, Ein Volk von fünfzehn Millionen Seelen, pp. 6-8.

${ }^{50}$ Emil Hervet, Ethnographie Polens. Bericht über die Arbeiten der Frau Severine Duchinska, Mitglied der ethnographischen und geographischen Gesellschaft von Paris gelesen in der ethnographischen Gesellschaft zu Paris in der Sitzung vom 15. März 1869, Vienna, 1871.

${ }^{51}$ See Hermann Ignaz Bidermann, Die ungarischen Ruthenen, ihr Wohngebiet, ihr Erwerb und ihre Geschichte, 2 vols, Innsbruck, 1862-67, vol. 2, pp. 7-22.

${ }^{52}$ Andrzej Nowak, Polacy, Rosjanie i biesy. Studia i szkice historyczne z XIX i XX wieku, Kraków, 1998, p. 138.

53 See idem, Jak rozbić rosyjskie imperium? Idee polskiej polityki wschodniej (1733-1921), Kraków, 1999, p. 268. 
in the pseudonym (S. Bezstronny - Impartial) under which Buszczyński published his anti-Russian tirades. ${ }^{54}$ The Kiev scholar gained much popularity in Poland in the period preceding the outbreak of the 1863 Uprising when it was easier for his works to be distributed without censorship. The Orgelbrand Encyclopedia's entry on Duchiński, authored at that time by Julian Bartoszewicz, contains the following information: 'Duchinski [...], to be honest, reiterated long held opinions on the problem which uneducated gentry of the Polish Republic had understood much better than some scholars of today'. ${ }^{55}$

The same reasons for which the theory became so popular in pre-insurrectionary Warsaw determined the Russian reception of it. Just as was the case with Duchiński's French followers, his Russian commentators, too, rarely acknowledged where the ideas originated. In 1863 Mikhail Pogodin wrote a polemical review of Duchiński's theses. ${ }^{56}$ Characteristically enough, it was not Duchiński but the editor-in-chief of Revue des Deux Mondes, Adolphe d'Avril, to whom Pogodin adressed his polemic. Avril, it is worth noting, offered a recapitulation of this Polish-Russian controversy surrounding the problem of the Slavic origin of the Russians, leaning towards Duchiński's view that there were serious anthropological differences to be discerned between the Muscovites and Ruthenians. ${ }^{57}$ Pogodin, in turn, contended that there was no point in arguing with Duchiński,

${ }^{54}$ S. Bezstronny [Stefan Buszczyński], Okrucieństwa Moskali. Chronologiczny rys prześladowania potomków Słowian przez carów i moskiewski naród od dawnych wieków aż do dni dzisiejszych. Przestroga historii dla południowej Słowiańszczyzny i tak zwanych panslawistów, Lwów, 1890; see also idem, Bestandteile der Russischen Bevölkerung und deren Confessionen von 85 Jahren, Lemberg, 1875; idem, Posłannictwo Słowian i odrębność Rusi. Rzut oka na Słowiańszczyznę, Kraków, 1885; idem, Rachunek polskiego sumienia. Rozmyślanie w niewoli, Kraków, 1883; Buszczyński is likely to have given a summarized account of Duchiński's ideas entitled Die Wunden Europas, Leipzig, 1875. On Buszczyński see Krzysztof Daszyk, Strażnik romantycznej tradycji. Rzecz o Stefanie Buszczyńskim, Kraków, 2001, in which the author steers carefully clear of the problem of racism in the anti-Russian concepts put forward by Duchiński and Buszczyński, highlighting instead the confluence of their ideas with those advocated by some Russian authors (ibid., pp. 158-62). See also [anon.] Życiorys Stefana Buszczyńskiego, Kraków, 1894. On the role of Duchiński’s theory in Buszczyński's works see Maciej Górny, 'Das ethnographische Motiv in den polnischen Föderationsplänen des 19. Jahrhunderts', in Option Europa. Deutsche, polnische und ungarische Europapläne des 19. und 20. Jahrhunderts, ed. Włodzimierz Borodziej and others, 3 vols, Göttingen 2005, vol. 1, pp. 187-204; and idem, 'Argument z etnografii w polskich planach federacyjnych XIX wieku’, Borussia, 2004, 35, pp. 139-50.

${ }^{55}$ Encyklopedia powszechna, 28 vols, Warsaw, 1859-68, vol. 7, 1861, p. 556.

${ }^{56}$ Mikhail Pogodin, Pol'skoi vopros. Sobranie razsuzhdenii, zapisok i zamiechanii, Moscow, 1863, pp. 124-44.

${ }^{57}$ V. de Mars [Adolphe d'Avril], 'La Pologne, ses anciennes provinces et ses véritables limites’, Revue des Deux Mondes, 33, 1863, 45, pp. 497-527. 
since his theory was nothing more than the expression of a disposition characteristic of the nation to which he belonged. At the same time, the Russian author was appalled at the fact that such ideas could find favour with serious scholarly journals in the West. ${ }^{58}$ Although both Pogodin and Viktor Stepanovich Poroshin, another Russian critic of Duchiński, tried to make their regard for Finns absolutely clear, they both put great emphasis upon the fact that whatever similarities were to be found between Fins and Russians, their source lay exclusively in similar environmental conditions. ${ }^{59}$ Duchiński was also given a half-hearted treatment in a small monograph written by the German geographer and expert on Russia, Johann-Heinrich Schnitzler. ${ }^{60}$ Garbling the name of the Polish scholar, Schnitzler managed to avoid making such a mistake with regard to both the Russian and French authors to whom he referred in his book. He summed up Duchiński's ideas in a rhetorical question: 'what is he trying to prove? That the real Ruthenia should belong to Poland?' ${ }^{61}$

At the beginning of the 1880s, Duchiński's work was singled out for as much praise as it was for criticism, the latter being even greater than that levelled at him by the Russian authors. In September 1885 he was awarded a commemorative medal designed by Karol Młodnicki. The medal had 'his portrait engraved on one side [...] and ethnographic maps showing Turan Moscow as clearly distinct from Atlantic Europe on the other. There was also an inscription engraved which read: "For the defender of historical truth in recognition of half a century of national service"'. ${ }^{62}$ Four years earlier Wacław Nałkowski published a pamphlet entitled 'On geographical errors on which Professor Duchiński's ideas are based', in which he attacked one of the pillars of Duchiński's theory: the geographical and anthropological border on the Dnieper river. ${ }^{63}$ Nałkowski treated the Kiev scholar's worldview with contempt, pejoratively calling it 'duchinizm' (duhinism) or 'duchinicznośc' (duhinishness). ${ }^{64}$ In an article published in 1885 in the journal Kraj ('Country'), and expanded later into a separate pamphlet (published also in Russian), Duchiński was attacked by Jan Baudouin de Courtenay. The noted linguist rejected the very idea of using science to

${ }^{58}$ Pogodin, Pol'skoi vopros, p. 125.

${ }^{59}$ Victor de Porochine, Une nationalité contestée. Russie - Pologne, Paris, 1862, p. 58.

${ }^{60}$ Jean-Henri Schnitzler, L'Empire des tsars au point actuel de la science, 4 vols, Paris, 1856-69, vol. 3, 1866; see also ibid., vol. 1.

${ }^{61}$ Ibid., vol. 3, p. 29 f.

${ }^{62}$ Duchińska, Wspomnienia, pp. 204-05.

${ }^{63}$ Wacław Nałkowski, O geograficznych błędach, na których opierają się historiozoficzne poglady profesora Duchińskiego, Warsaw, 1881.

${ }^{64}$ Ibid., p. 54. 
promote a political agenda, directing his criticism both at Russian Slavophiles and Duchiński. 'Our ethnographer', he wrote 'preaches a gospel of love between Aryan nations. This love goes hand in hand with the Aryans' indifference, if not hatred, towards the Turan world. And since all the European nations living west of the Dnieper river and "small rivers of Finland" are counted among the Aryan world, the theory is, to be sure, designed to bolster the cause of uniting the whole of Europe, including Aryan Poland, with a view to pushing Turan Moscow back to the east'. ${ }^{35}$ The real blow was also dealt by Duchiński's countryman, Myhailo Drahomanov, who totally rejected Duchiński's theories, concentrating his criticism on views regarding the Turan origin of Cossacks. ${ }^{66}$

When Duchiński's life was nearing its end, every single trope followed by the authors commenting on his work had already crystallized. Both Polish and Ukrainian scholars turned to Duchiński for ethnographic and anthropological arguments - just as during his greatest scholarly triumphs after 1863 - to support the theory which excluded Russia from Europe. In the twentieth century, too, there were authors who continued to make similar use of Duchiński's work. Lonhyn Tsehel's'kyi, for example, contended in 1915 that 'in racial terms Russians are not Slavs but only slavicized Finns'. ${ }^{67}$ As we have already seen, historians have tended to pass a very severe judgment on Duchiński's writings, which is best seen in the title of the paper on his thought written by Andrzej Feliks Grabski 'Na manowcach myśli historycznej' ('Historical thought led astray'). Approached from this angle, Duchiński is believed to have perverted the course of nineteenth-century Polish historical thought by reducing to absurdity views and ideas expounded by such thinkers as Adam Mickiewicz, Joachim Lelewel and Maurycy Mochnacki. ${ }^{68}$ The approval with which Duchiński's theories met in the West must, in turn, be

${ }^{65}$ Jan Baudouin de Courtenay, Z powodu jubileuszu profesora Duchińskiego, Kraków, 1886, p. 24.

${ }^{66}$ Myhailo Drahomanov, Pro ukraïns'kyh kozakiv, tatar ta turkiv, Kyïv, 1876; see the polemic [F.H. Duchiński], Qui sont les Kosaks?, Paris, 1877.

${ }^{6}$ 'Die Russen ihrer Rasse nach ja gar keine Slawen, sondern slawisierte Finnen sind': Longin Cehelskyj, Die großen politischen Aufgaben des Krieges im Osten und die ukrainische Frage, Berlin, 1915, p. 31. Similar comments including references to Duchiński can be found in Ludwik Kulczycki, Panslawizm a sprawa polska, Kraków, 1916, p. 11. The author clearly distances himself from Duchiński's theories.

${ }^{68}$ Among the great number of works dealing with the problem of the relation of the Polish political thought to Russia in the nineteenth century the work which sheds most light on the problem is Wierzbicki, Groźni $i$ wielcy. These issues are also analysed by Irena Grudzińska-Gross, Piętno rewolucji. Custine, Tocqueville, Mickiewicz i wyobraźnia romantyczna, Warsaw, 2000. 
viewed through the prism of Russophobic nature of Western liberalism - a point that has been noted by Hans Henning Hahn. ${ }^{69}$

An attempt to add new names to the list of the authors interested in Duchinski and to present more interpretations of the extravagant views to which he adhered is likely to be both interesting and instructive, but it is highly unlikely to result in new insights into his oeuvre. In order achieve this goal, we shall instead employ something of a comparative method which, as Marc Bloch and Jürgen Kocka have suggested, allows us to identify problems which would have otherwise gone unnoticed ${ }^{70}$. In what follows, we also draw inspiration from recent methodological debates among scholars of the so-called histoire croisée. The latter seems to be particularly helpful in studying ideology, as well as intellectual and scholarly life. ${ }^{71}$

It is Jean-Louis Armand de Quatrefages, the French anthropologist, whom we shall compare with Duchiński. Or, to be more precise, it is one isolated episode in Quatrefages's intellectual biography - one in which his scholarly activity became entirely subordinated to politics - that will serve here as a comparative point of reference. Quatrefages and Duchiński knew each other. The Kiev scholar met his future wife in May 1864, listening to lectures delivered by the French anthropologist in the Paris botanic garden. ${ }^{72}$ Both were members of the Geographical Society. At the outbreak of the Franco-Prussian war, Duchiński and his wife were staying at a healing resort in Bohemia, and because of the ongoing war (and later because of increasing Russian influence in French politics) the couple did not arrive back in Paris until March 1872. The couple's return to France was to remain deeply engraved in the memory of Seweryna Duchińska: 'One evening we went to a meeting of the Geographical Society. The view which emerged there before our eyes was truly horrifying. Each of the scholars had grown older by ten years. Quatrefages's hair had turned grey'. ${ }^{73}$

${ }^{69}$ Hans Henning Hahn, Dyplomacja bez listów uwierzytelniajacych. Polityka zagraniczna Adama Jerzego Czartoryskiego 1830-1840, Warsaw, 1987, p. 321; see also Ezequiel Adamovsky, Euro-Orientalism. Liberal Ideology and the Image of Russia in France (c.1740-1880), Bern, 2006, p. 13.

${ }^{70}$ Marc Bloch, 'Pour une histoire comparée des sociétés européennes' (1928), in: idem, Mélanges historiques, 2 vols, Paris, 1963, vol. 1, pp. 16-40; Heinz-Gerhard Haupt and Jürgen Kocka, 'Vergleichende Geschichte: Methoden, Aufgaben, Probleme', in Geschichte und Vergleich. Ansätze und Ergebnisse international vergleichender Geschichtsschreibung, ed. Heinz-Gerhard Haupt and Jürgen Kocka, Frankfurt am Main and New York, 1996, pp. 9-45.

${ }^{71}$ Michael Werner and Bénédicte Zimmermann,'Beyond Comparison. Histoire Croisée and the Challenge of Reflexivity', History and Theory, 45, 2006, pp.30-50.

${ }^{72}$ See Duchińska's account of the event: Wspomnienia, p. 16.

${ }^{73}$ Ibid., p. 113. 
The French anthropologist may have been dejected not only by his country's defeat in the war but also by the losses that French science suffered during the siege of Paris. The bombardment of the Paris Museum in January 1871 caused much damage to zoological, botanical, and anthropological collections (although none of the museum staff were injured). Quatrefages suspected the Prussians of trying deliberately to destroy some valuable collections in an effort to weaken French science. His reaction was swift and decisive. He wrote a paper on the Prussian race. ${ }^{74}$ It appeared in Revue des Deux Mondes, but was also published in the form of a separate pamphlet, first in French and after a few months in English. It is this publication that won him a place in history books on European racism. ${ }^{75}$

Quatrefages's pamphlet starts with assurances of the author's scholarly objectivity. He expresses the view that 'every political subdivision, founded on ethnology, immediately leads to absurdity' ${ }^{76}$ Nevertheless, despite his avowed caution, like Duchiński he analysed the physical appearance of the members of the Turan race. However, it was not Prussians, to whom the pamphlet was supposed to be devoted, but Estonians to whom he assigned the role of representing the race in question. It is common knowledge, says Quatrefages, that they speak a non-Aryan language resembling Finnish. It is also in terms of their physical appearance that they are similar to Finns:

Their bust is long; their legs short, and the region of the pelvis large in proportion to that of the shoulders. [...] The eyes [...] are generally deeply

${ }^{74}$ Armand de Quatrefages, 'La Race prusienne', Revue des Deux Mondes, 41, 1871, 91, pp. 647-69. Henceforward all quotations are taken from Jean-Louis Armand de Quatrefages, The Prussian Race Ethnologically Considered. To Which is Appended Some Account of the Bombardment of the Museum of Natural History, etc. by the Prussians in January 1871, London, 1872.

${ }^{75}$ See, for example, Juan Comas, Racial Myths. The Race Question in Modern Science, Paris, 1958, pp. 42-48; Leon Poliakov, Der arische Mythos. Zu den Quellen von Rassismus und Nationalismus, Hamburg, 1993, pp. 295-97; idem, Christian Delacampagne and Patrick Girard, Über den Rassismus. Sechzehn Kapitel zur Anatomie, Geschichte und Deutung des Rassenwahns, Frankfurt am Main, 1984; Lothar Baier, 'Odwracalność stereotypów przykład francusko-niemiecki', in Narody i stereotypy, ed. Teresa Walas, Kraków, 1995, pp. 194-97; Ivan Hannaford, Race. The History of an Idea in the West, Washington, DC, 1996, pp. 287-90; Popowicz, Lamarkizm społeczny a rasizm i eugenika, pp. 170-72; Gerhard Ahlbrecht, Preußenbäume und Bagdadbahn. Deutschland im Blick der französischen Geo-Disziplinen (1821-2004), Passau, 2006; and also older works accepting racial assumptions, for example William Z. Ripley, The Races of Europe. A Sociological Study, New York, 1899, pp. 219-21; idem, 'The Racial Geography of Europe', Appleton's Popular Science Monthly, 52, 1898, pp. 49-56.

${ }^{76}$ Quatrefages, The Prussian Race, p. 2. 
set; the nose, straight and but little rounded, is often too small for the width of the cheeks, and the space separating it from the mouth is too. ${ }^{77}$

Having characterized the Estonians, he turns to depicting the Latvians. The latter, in contrast to their neighbours from the North, use the Aryan language. However, from the anthropological point of view, they need to be ranked among a 'group of races named by turn Tchudes, Mongolians, Turanians, and North Ouralians'. ${ }^{78}$ With the ground thus prepared, Quatrefages tries to develop his argument by drawing on an observation made by another member of the Anthropological Society, Charles Rochet, on the appearance of Prussian soldiers from Pomerania. ${ }^{79}$ Although Prussians are a little taller than Estonians and Latvians, there is clearly, according to both French scholars, a far-reaching resemblance between them.$^{80}$ Their disproportionate shapes - similar to those discerned by Duchiński in the Muscovites - stemmed from the fact that Finns were descendants of the most primordial and, by extension, the most primitive people in Europe - paleolithic hunters. And at this point Quatrefages referred back to Duchiński's opinion indicating the Lithuanians' physical likeness to the Bretons. From this it followed, according to the French anthropologist, that it was the common Finnish component - which in Lithuanians combined with the Aryan traits of Slavs and in Bretons with the Aryan traits of Celts - that must have been responsible for the development of features commonly characterizing both groups. ${ }^{81}$

Finns, continues Quatrefages, are both physically and psychologically distinct from Aryans. They are calm, deeply attached to their own traditions, but also mistrustful:

Unhappily all the good in this picture is marred by a quality which seems to be thoroughly national. The Finn never pardons a real or supposed offence, avenges it on the first opportunity, and is not fastidious in his choice of means. Thus is explained the frequency of assassination in Finland amongst the peasants. ${ }^{82}$

The qualities of Prussia's primordial inhabitants, conquered later by Slavs, merged with the conquerors' worst qualities - a lust for conquest

${ }^{77}$ Ibid., p. 19.

${ }^{78}$ Ibid., p. 21.

${ }^{79}$ Charles Rochet, 'Communication sur le type prussien', Bulletins de la Société d'Anthropologie de Paris, 1871, pp. 75-77 and 188-96.

${ }^{80}$ Quatrefages, The Prussian Race, p. 37.

${ }^{81}$ Ibid., p. 35.

${ }^{82}$ Ibid., p. 61. 
and proclivity for betrayal. Germans were the next group to subjugate the local population, absorbing old-Prussian elites and, according to Quatrefages, benefitting Prussians in the greatest degree. But it was the French Huguenots who managed to secure for themselves a dominant position within the élite of the country, becoming the only group capable of producing high cultural values.

The fact that Prussians constituted - according to Quatrefages's characterization - a mixture of four nations and two races, Finno-Turan primordial Prussians, Aryan Slavs, Germans and the French, did not mean that their qualities were merely an amalgam of the qualities possessed by each of the races. Quite the contrary, the two primordial groups were able to dominate those who arrived later: 'The German or the Frenchmen would naturally turn into a Slav or a Finn'.$^{83}$ This was to be particularly conspicuous in the French who were still bound through language with their old motherland, but who from the racial viewpoint had already been 'Prussianized': 'Men were to be found only too easily in all ranks of the Prussian population and army who spoke French purely and without a German accent. These had no difficulty in passing themselves off as Frenchmen, in slipping in everywhere, in surprising and betraying what it was most important for us to conceal, and in preaching undiscipline and insurrection'. ${ }^{84}$ The fate suffered in France by Huguenot families was a blow to both those families and to France itself. Quatrefages, who was a Protestant himself, wept bitterly over their misery which finally turned out to be a factor in France's defeat. Moreover, these French Protestants, who had once been forced to abandon France, failed to reach the level of racial maturity that had already been achieved by their former brothers in the old country. This was because the Prussian race was not yet fully shaped. Instead it was still passing through the barbarian stage of its development.

An interesting aspect of Quatrefages's remarks concerns the relationship between Germans and Prussians. At this point, too, his views are clearly in keeping with those articulated by Duchiński. The French anthropologist arrived at the conclusion that, in racial terms, Germans were a world apart from Prussians. The acceptance of the Prussian leadership by Germans should be regarded as a misunderstanding, an 'anthropological mistake', for 'in every respect, Prussia is ethnologically distinct from the peoples she now rules over, through the plea of a (pretended) unity of race'.$^{55}$

\footnotetext{
${ }^{83}$ Ibid., p. 65.

${ }^{84}$ Ibid., p. 85.

${ }^{85}$ Ibid.
} 
In the conclusion of his work, Quatrefages made one more reference to Duchiński without mentioning his name. After France's defeat, dark clouds, he wrote, were gathering over Europe; for Prussian pan-Germanism was raising the spectre of Russian pan-Slavism. 'In the possible conflicts caused by these pretensions, what will Prussia do? Will she turn her cannon against her formidable neighbour? Or will she then invoke the affinity of race, as she now invokes the affinity of language, rivet the bonds which already exist? Will the Slavo-Finnic races wish to reign altogether, over Germans and Latins? And would the world, thus shared, submit in silence?'. ${ }^{86}$

Unlike other French authors writing about Turans, Quatrefages wrote his pamphlet alone. The fact that the views articulated in his work were in several ways similar to those held by Duchiński was not just the result of mere imitation. During his short stay in Paris in the spring of 1872, Duchinski tried to develop further the part of Quatrefages's argument which he regarded as most important. At the meeting of the Geographical Society held on 19 April 1872, Duchiński delivered a lecture in which he developed and modified the line of reasoning followed by Quatrefages in the conclusion of his work on the Prussian race. Pan-Slavism, he argued, should be treated as an exact copy of pan-Germanism, that is, as nothing but a tool likely to be used for legitimizing the idea of ruthless conquest. At the same time, he expressed an opinion which ran counter to what Quatrefages had written, namely that people who inhabited the areas east of the Dnieper River were not a Slav-Finnic mixture, representing instead a pure Asian, Turan race. ${ }^{87}$ To be sure, for the advocates of Duchiński's theories it was simply out of the question to link Slavs with Finns. The fact that Quatrefages viewed the former as ranking among the Aryan race still was not enough to satisfy Duchiński's followers.

While the pamphlet dealing with the Prussians could not borrow too much from works on the Russians, structural parallels discerned in the works of both scholars are striking. A theory popular in the nineteenth century which fed upon some remarks found in Tacitus' Germania served as a point of departure for both scholars. According to this theory, Finns were the first savage population to have inhabited northern Europe, long before the advent of the Aryan people. ${ }^{88}$ In describing the physical traits

\footnotetext{
${ }^{86}$ Ibid., pp. 86-87.

87 'Société de géographie. Séance du 19 avril [1872]', La Revue Politique et Littéraire. Revue des Cours Littéraires, ser. 2, 1, 1872, 44, pp. 1044-45.

${ }^{88} \mathrm{See}$, for example, James Covles Prichard, Eastern Origin of the Celtic Nations, Oxford, 1831; for more on the problem of nineteenth-century interpretations concerning the ethnogenesis of the Finns see Anssi Halmesvirta, The British Conception of the
} 
of the Turan race, both authors drew attention to the fact that Turans were not proportionally built.

In characterizing a Muscovite, Duchiński is likely to have had before his eyes a figure resembling an Estonian or a Latvian as found in the work of Quatrefages. There are also some clear similarities present in the psychological characterization of the races in question offered by both authors. Both groups of Turans are believed to be guided in their social life by veneration for power and lust for conquest. Differences between them are either apparent or of secondary importance. While Duchiński claims that the Muscovites have no difficulty in forsaking their traditions, Quatrefages argues that Finns are deeply attached to theirs. However, when one takes a closer look at the analyses carried out by both scholars, then it turns out that Duchiński did not fail to see that some basic elements of the Turan culture and psyche refused to lend themselves to change. In turn, Quatrefages noted that both 'autochthonic' Prussian races tended to copy the cultural patterns of others ${ }^{89}$ Both visions drew heavily on the views - very popular at that time - that divided human kind into 'active' and 'passive' races, or, as in the works by Gustav Klemm, into 'male' or 'female' people..$^{90}$ The most important, one might say 'practical', conclusion to be drawn from the works of both scholars concerns the mechanism of exclusion from the European family of nations. Both Duchiński and Quatrefages carry out the same manoeuvre of separating the elements they regard as racially alien from those they consider racially related. Duchiński launches into the struggle for perpetuating the image of Ruthenia as racially different from Moscow. Quatrefages tries to 'save' for the Aryan race Germans from western and southern Europe.

To detect significant differences one needs to look not so much at the structure of both theories as to the narrative styles. Quatrefages declares his adherence to such values as scholarly objectivity and common sense. Accepting the idea of the inequality of races, he criticizes the theory, assumed to be entertained by Prussians, that races are necessarily hostile to each other. In terms of scholarly apparatus, he remains in harmony with the ideologized, but logically impeccable, exposition of his

Finnish 'Race', Nation and Culture, 1760-1918, Helsinki, 1990; and A. Kemiläinen, Finns in the Shadow of the 'Aryans'. Race Theories and Racism, Helsinki, 1998.

89 'The Fin or the Slave might ameliorate the conditions of his existence, change his religion, cultivate his mind, and raise his intelligence, but his fundamental nature must necessarily remain the same', Quatrefages, The Prussian Race, p. 64.

${ }^{90}$ Gustav Klemm, Cultur-Geschichte des christlichen Europa, 2 vols Leipzig, 1851-52, vol. 2: Osteuropa. 
views. In contrast, Duchiński appears to be a talented amateur. He invokes the authority of science, trying to keep his line of reasoning as clear and coherent as possible. But at the same time he makes no secret of the fact that the most important task he has set himself does not consist of contributing to the progress of science or to the development of knowledge, but to the liberation of Poland and Ukraine. Science is just one of the means - and obviously not the most important - that can be used to achieve the political goal he has in mind. During the celebrations of fifty years of his scholarly work in 1885 , he expounded views which Quatrefages would probably never have claimed to hold:

We have raised five great armies against our enemies [...]. The first army of ours is the trust we put in God that He will never allow the lie to prevail. The second army - ethnography. The third one - geography in the widest possible sense of the term. The fourth army - statistics. And the fifth - philosophy. It is those armies that we are going to lead into battle - sometimes relying only on some of them, and sometimes using them all at once. ${ }^{91}$

The French edition of the work of Max Müller (La Science de la religion), one of the proponents of the 'Aryan myth', containing critical comments penned by Duchiński's wife in the margins of the text (held by the National Library in Warsaw) is a very interesting document. It sheds much light upon the religious perspective which can clearly be detected in the opinion quoted above and which was evidently shared by the married couple. ${ }^{92}$ Müller considers the correct method of classifying different religions and arrives at the conclusion that 'the only true and proper classification of religions is the same as the classification of languages'. Duchińska's comment on this opinion attests to her holding of a different worldview. 'This lies in God's jurisdiction. And God speaks through substantive laws'..$^{93}$

All the parallels between the racial theories developed by Duchiński and Quatrefages are grounded in the identical positions they occupied and in the similarly identical discourse within which they operated. Direct references were of secondary importance. It is no coincidence that Quatrefages, in preparing the pamphlet edition of his text, removed some direct references to Duchiński which had previously been included in the paper published in Revue des Deux Mondes. In this paper he also added a footnote

${ }^{91}$ Franciszek Henryk Duchiński, Drugi mój 25-letni jubileusz, Paris, 1885, p. III.

${ }^{92}$ Friedrich Max Müller, La Science de la religion, Paris, 1873.

${ }_{93}$ Ibid., p. 71; quotation from idem, Religia jako przedmiot umiejętności porównawczej. Wykłady, Kraków, 1873, p. 55. 
to a passage concerning the Slavs. The footnote referred to the maps prepared by Duchiński and used by Vicquesnel. ${ }^{94}$ but it remains absent from further editions of 'La Race prusienne'. One may presume that it was the change in the European constellation of powers that made the appeal to an anti-Russian emigrant no longer appealing. Besides, in the $1870 \mathrm{~s} \mathrm{Du}-$ chiński - unlike Quatrefages - was not at the height of his intellectual powers and his theories had already begun to lose popularity. French Polonophilia had also lost momentum, especially in conservative and liberal circles horrified by the spectre of a recurring Commune and the linking of the Polish problem with political and social radicalism. ${ }^{95}$ The affinity of ideas held by both anthropologists became less noticeable as the number of people familiar with Duchiński's work dwindled. However, this does not mean that the extent to which Quatrefages's work was indebted to Duchiński's ideas went completely unnoticed. At the beginning of 1873 the London Pall Mall Gazette - a liberal-leaning newspaper - offered in its editorial a mocking criticism of a plan to organize an expedition to search for the ten lost tribes of Israel, which recalled Duchiński's view that the Moscow Turans are a Semitic people. The acceptance of this view - written ironically by the author of the article - leads logically to the conclusion that this expedition should set out for Russia. For the reader who had never heard of Duchiński the editorial added a short note: 'Duchiński, the polemical ethnologist of Russia and Poland (from whose arsenal that inferior warrior M. Quatrefages has borrowed the weapons he employs against "la race Prussienne")'. ${ }^{96}$

The reception of 'La Race prussienne' also played a part in Quatrefages's intellectual indebtedness to Duchiński disappearing into oblivion. Quite naturally, Quatrefages' work attracted mainly the interest of French and Prussian scholars for whom the question of the range of Slavic settlements in the east was clearly of secondary importance. They focused their attention on the population inhabiting the Baltic coast. In France there appeared a great number of authors who followed in Quatrefages's footsteps, trying to prove, like Louis Figuier, that the same cruelty which once characterized Finns now characterized modern Prussians in whom it had simply been brought back to life. ${ }^{97}$ Racial theories became one of the more

${ }^{94}$ Quatrefages, 'La Race prusienne', p. 649.

${ }_{95}$ Ernst Birke, Frankreich und Ostmitteleuropa im 19. Jahrhundert. Beiträge zur Politik und Geistesgeschichte, Cologne, 1960, pp.366-67.

${ }^{96}$ The Ten Tribes, quotation from the Evening Post (Wellington, NZ) 8, 1 February 1873,308, p. 2.

${ }^{97}$ Louis Figuier, Tableau de la nature. Les races humaines, Paris, 1872; see Poliakov, Der arische Mythos, p. 295. 
interesting currents of French nationalism..$^{98}$ On the other hand, the Reich relied on the same arguments for demonstrating the close ties connecting the annexed provinces (Alsace and Lorraine) with Germany. ${ }^{99}$

On 14 October 1871, during the proceedings of the German Anthropological Society, a geographer and cartographer, Heinrich Kiepert, presented Quatrefages's main theses. Those present at the meeting did not try to conceal their indignation at what they heard. ${ }^{100}$ The reaction of Rudolf Virchow, a co-founder of the Society, was more restrained but at the same time more practical. During one of the later meetings of the Society he told the members the information he had received from the Swedish anthropologist of Helsingfors (Helsinki), Otton Hjelt. The latter, however confirming Duchiński's thesis about Finns' vengefulness, denied that they showed a propensity for treason or cruelty. ${ }^{101}$ In September 1873 Virchow informed the Society of the plans for taking anthropological measurements of German students (he deplored that the Prussian army had refused to give consent to carry out this operation among German recruits). This anthropological 'scrutiny' finally encompassed several million people. ${ }^{102}$ At the same time he sent an official request to the Russian authorities for their consent to carry out similar research in Finland. Both these great research projects, as he explained, were to serve the purpose of verifying Quatrefages's theses:

Gentlemen, you know that the French conflict has fostered the belief that central Europe is inhabited by two categories of people. The first consists of the descendants of the ancient population of the area. Slightly built, they have dark eyes, dark hair, and in varying degrees dark skin, and are

98 Susanne Michl, Im Dienste des 'Volkskörpers'. Deutsche und französische Ärzte im Ersten Weltkrieg, Göttingen, 2007, pp. 60-63; Gonthier-Louis Fink, 'Der janusköpfige Nachbar. Das französische Deutschlandbild gestern und heute', in Fiktion des Fremden. Erkundung kultureller Grenzen in Literatur und Publizistik, ed. Dietrich Harth, Frankfurt am Main, 1994, pp. 21-56; Heidi Mehrkens, Statuswechsel. Kriegserfahrung und nationale Wahrnehmung im Deutsch-Französischen Krieg 1870/71, Essen, 2008, passim. For a more detailed analysis of this aspect of racial discourse in France see Carole Reynaud-Paligot, La République raciale. Paradigme racial et idéologie républicaine (1860-1930), Paris, 2006.

${ }_{99}$ Wolfgang Freund, 'Disputierte Bevölkerung. Der gelehrte Streit um die Menschen an der deutsch-französischen Grenze', in Bevölkerungsfragen. Prozesse des Wissenstransfers in Deutschland und Frankreich (1870-1939), ed. by Patrick Krassnitzer and Petra Overath, Cologne, 2007, pp. 210-15.

100 'Sitzungen der Localvereine', Correspondenz-Blatt der deutschen Gesellschaft für Anthropologie, Ethnologie und Urgeschichte, 1871, 11, p. 83.

101 'Sitzungsberichte der Localvereine', Correspondenz-Blatt der deutschen Gesellschaft für Anthropologie, Ethnologie und Urgeschichte, 1872, 5, p. 33.

${ }^{102}$ See Paul Weindling, Health, Race and German Politics Between National Unification and Nazism, 1870-1945, Cambridge, 1989, pp. 48-49. 
now known as the Finnic or Estonian race. [...] The second comprises those who arrived here later and who - representing the Aryan race are believed to be very tall, strong-built, and possessed of blue eyes and pale skin. Thus in the eyes of our western colleagues, there is really no point in trying to distinguish between Celts, Germans, and Slavs. An Aryan is supposed to have blue eyes and blond hair. He must be tall, strong, and of pale complexion. ${ }^{103}$

The anthropological survey yielded results which entirely disproved Quatrefages's theses. The operation of measuring students' physical build demonstrated that anthropological traits usually attributed to Aryans typified the inhabitants of Prussia, being particularly prevalent among those who lived along the Baltic coast. In 1874, upon his return from Finland, Virchow stated that in that country - just like in the rest of Europe - one could find both long and short skull types. Moreover, he made a claim that in anthropological terms the population of Finland differed little from that of Russia. This in turn led him to form the opinion that 'relying on anthropology is clearly a flawed strategy to be employed by Panslavism in searching for its own legitimacy'. ${ }^{104} \mathrm{He}$ concluded his speech with a statement which in his opinion also put an end to the whole debate. 'We are not in a position to state beyond any doubt whether any of the tribes of central Europe is Indo-European or Finnish'. ${ }^{105}$

As is well-known, the impression that empirical research managed to close the discussion of the racial problem in central Europe proved false.

103 'Sie wissen, dass gerade durch den französischen Streit die Meinung in der Vordergrund getreten ist, dass es auf dem Gebiete des mittleren Europas zwei Kategorien von Bevölkerungen gebe, nämlich eine uralte Aboriginerbevölkerung, welche sich vorzugsweise durch kleineren und schwächeren Körperbau, durch dunkle Farbe der Augen und des Haares, sowie zum Theile auch der Haut auszeichnen soll und welche die finnischen oder der estnischen [...] Rasse zugerechnet wird, und eine arische Einwanderung [...], von der man [...] behauptet, dass sie gross, sogar sehr gross, blond, blauäugig, hellfarbig und stark gewesen sei. Das Celtische, Germanische oder Slawische erscheint in diesem Augenblicke den Augen unserer westlichen Collegen gleichgültig; ist jemand arisch, so muss er blauäugig, blond, gross, stark und hellfarbig sein', Rudolf Virchow, [contribution to the discussion], in Die vierte allgemeine Versammlung der deutschen Gesellschaft für Anthropologie, Ethnologie und Urgeschichte zu Wiesbaden am 15. bis 17. September 1873, ed. Alexander von Frantzius, Braunschweig, 1874, p. 28.

104 'Wenn also der Panslawismus im Augenblicke vom anthropologischen Standpunkte aus sich construiren will, so hat das seine misslichen Seiten', Rudolf Virchow, 'Über die Verbreitung brachycephaler Schädel in vorgeschichtlicher und geschichtlicher Zeit in Deutschland', in Die fünfte allgemeine Versammlung der deutschen Gesellschaft für Anthropologie, Ethnologie und Urgeschichte zu Dresden vom 14. bis 16. September 1874, ed. Hermann von Ihering, Braunschweig, 1875, p. 14.

105 'Das ist also unzweifelhaft, dass wir nicht in der Lage sind, einfach zu sagen, es sei ein Volk oder ein Volksstam in Mitteleuropa indogermanisch oder finnisch', ibid., p. 15. 
In the following decades the 'Aryan myth' and Nordic theory gained much popularity in Germany. The question of Indo-Germans became a political one, with Indo-Germans being usually identified with Germans. It is this process that has been particularly well explored by historians involved in the study of the history of ideas. ${ }^{106}$

The histoire croisée of scholarly disciplines as understood by Michael Werner and Bénédicte Zimmermann sets itself the task of revealing the network of connections between different fields of study and between different national contexts. Such an approach encourages attempts to go beyond old interpretative patterns. ${ }^{107}$ In the above, we have combined different aspects of three traditional research strategies. One of these approaches is connected with studies in the history of historiography inaugurated in Poland by such scholars as Marian Henryk Serejski and Andrzej Feliks Grabski and presently continued by Andrzej Wierzbicki. Issues addressed by such scholars step outside 'pure' historiography, venturing into the realm of the historical imagination characterizing past societies. With boundaries of the discipline thus circumscribed, Franciszek Duchiński in his capacity as a philosopher of history remains 'naturally' within the focus of its interest. On the other hand, racial theories lie within the framework of nationalistic discourse, thus attracting the attention of historians of nationalism - in so far as Quatrefages is concerned, it is of course especially French and German nationalisms. ${ }^{108}$ Last but not least, the Franco-German 'war of professors' makes up part of the story of European racism. The role of Quatrefages in this was crucial, while that of Duchiński was marginal.

A matter of secondary importance for Polish historiography is that Duchiński's ideas not only found a number of followers, but that they also inspired an analogous theory put forth by Quatrefages. Directed against Russia, Duchiński's theory which linked the anthropological origin of the Muscovites with a Turan race was used by the French scholar who 'shifted' it in space and applied it to Prussians. Quatrefages drew on more than one

${ }^{106}$ Among the great body of literature on the problem one can confine oneself to mentioning some classic studies: Georg L. Mosse, The Crisis of German Ideology: Intellectual Origins of the Third Reich, London, 1964; Peter Weingart, Jürgen Kroll and Kurt Bayertz, Rasse, Blut und Gene. Geschichte der Eugenik und Rassenhygiene in Deutschland, Frankfurt am Main, 1988. The institutional development of German studies on race was summarized in an encyclopedic form in Handbuch der völkischen Wissenschaften. Personen, Institutionen, Forschungsprogramme, Stiftungen, ed. Ingo Haar, Michael Fahlbusch and Matthias Berg, Munich, 2008.

107 Werner and Zimmermann, 'Beyond Comparison', p. 49.

${ }^{108}$ See Cordula Tollmien, 'Der "Krieg der Geister" in der Provinz - das Beispiel der Universität Göttingen 1914-1919’, Göttinger Jahrbuch, 41, 1993, pp. 180-210. 
strand of Duchiński's argument, preserving, at least implicitly, its anti-Russian character. For Virchow, who passed a devastating criticism of the theory, it was still easy to recognize the connection between the view indicating the Finnish origin of Prussians and that concerning the ethnoghenesis of Russians. The later reception of Quatrefages's work became increasingly isolated from the thesis postulated by Duchiński. European racists were no longer interested in the ideas of the Polish emigrant. Serious ethnologists or anthropologist felt no need to study the origins of the views they criticized. For the latter it was unacceptable to liken any academic discipline to armies sent into battle with a view to fighting the enemy of the fatherland. The weekly Nature, in the third year of its publication, commented on this in the following way: 'We think an ethnological journal is not the place for international warfare'. ${ }^{109}$

(Translated by Artur Mękarski)

\section{Summary}

This article by Maciej Górny discusses the works of two nineteenth-century anthropologists: Franciszek Duchiński (1816-93) and Jean-Louis Armand de Quatrefages de Bréau (1810-92). The methodological foundation of the text is the conception of histoire croisée. The first of the above-mentioned scholars was a Polish political émigré born in Ukraine and living in Turkey, France and Switzerland, the author of a theory about the non-Slavonic racial origin of the Russians. In the 1860s and 1870s his theses became widely known in France and German-speaking countries. Quatrefages became acclaimed for his publication La Race prussienne, maintaining that the Prussians are of Turan (Mongol) origin. The topic of the discussed article also embraces the international reception of both authors: Jean-Louis Quatrefages has been assigned a place both in the history of science and in works on the history of European racism, while Franciszek Duchiński has been relegated to the margin of Polish and Ukrainian history of historiography.

Maciej Górny conducted a comparative analysis of the theses propounded by the two authors. Consequently, and upon the basis of assorted evidence documenting contacts maintained by Quatrefages and Duchiński we might assert that La race prussienne was in part plagiarism of the publication by the Polish-Ukrainian anthropologist and partly an adaptation of his theses to slightly different research material.

(Translated by Aleksandra Rodzińska-Chojnowska)

109 'Scientific serials', Nature, 30 May 1872, p. 93. 